Rueda-Hernandez, R., I. MacGregor-Fors, and K. Renton. 2015. Shifts in resident bird communities associated with cloud forest patch size in Central Veracruz, Mexico. Avian Conservation and Ecology 10(2): 2. http://dx.doi.org/10.5751/ACE-00751-100202

Copyright (C) 2015 by the author(s). Published here under license by the Resilience Alliance.

Research Paper

\title{
Shifts in resident bird communities associated with cloud forest patch size in Central Veracruz, Mexico
}

\author{
Rafael Rueda-Hernandez ${ }^{1}$, Ian MacGregor-Fors ${ }^{2}$ and Katherine Renton ${ }^{3}$ \\ ${ }^{1}$ Posgrado en Ciencias Biológicas, Instituto de Biología, Universidad Nacional Autónoma de México, ${ }^{2}$ Red de Ambiente y \\ Sustentabilidad, Instituto de Ecología, A.C., ${ }^{3}$ Estación de Biología Chamela, Instituto de Biología, Universidad Nacional \\ Autónoma de México
}

\begin{abstract}
Avian communities in cloud forests have high levels of endemism and are at major risk given the accelerated rate of habitat fragmentation. Nevertheless, the response of these communities to changes in fragment size remains poorly understood. We evaluated species richness, bird community density, community composition, and dominance as indicators of the response to fragment size in a fragmented cloud forest landscape in central Veracruz, Mexico. Medium-sized fragments had statistically higher than expected species richness and more even communities, which may be a reflection of the intermediate disturbance hypothesis, in which mediumsized fragments are exploited by both forest and disturbance-associated species. Bird density also reached higher values in mediumsized fragments, which may indicate a carrying capacity in this habitat. However, large cloud forest fragments had a distinct taxonomic and functional composition, attributable to an increased number of understory insectivore species and canopy frugivores. By comparison, omnivorous species associated with human-altered habitats were more abundant in smaller fragments. Hence, although medium-sized cloud forest fragments had higher species richness and high bird density, large forest tracts maintained a distinct avian community composition, particularly of insectivorous and frugivorous species. Furthermore, the underlying response to fragmentation can only be properly addressed when contrasting several community attributes, such as richness, density, composition, and species dominance. Therefore, cloud forest conservation should aim to preserve the remaining large forest fragments to maintain comprehensive avian communities and avoid local extinctions.
\end{abstract}

\section{Changements dans les communautés d'oiseaux résidents associés à la dimension des îlots de forêts de nuages dans le centre du Veracruz, Mexique}

RÉSUMÉ. Les communautés aviaires des forêts de nuages (c.-à-d., les forêts humides de montagne) ont un degré d'endémisme élevé et sont très menacées considérant le rythme accéléré de la fragmentation de l'habitat. Néanmoins, la réponse de ces communautés en réaction aux changements de la dimension des îlots demeure largement inexpliquée. Nous avons évalué la richesse spécifique, la densité des communautés aviaires, la composition des communautés et la dominance spécifique comme facteurs pouvant expliquer la réponse à la dimension des îlots dans un paysage fragmenté de forêts de nuages dans le centre du Veracruz, Mexique. Les îlots de taille moyenne ont montré une richesse spécifique attendue plus élevée statistiquement que les autres îlots et des communautés plus uniformes, résultat qui pourrait s'expliquer par l'hypothèse de perturbation intermédiaire selon laquelle les îlots de taille moyenne sont exploités autant par des espèces forestières que des espèces associées aux perturbations. Les valeurs de densité aviaire ont aussi été plus élevées dans ces îlots, ce qui pourrait indiquer que ce milieu a atteint sa capacité de support. Toutefois, les grands îlots de forêts de nuages ont montré une composition distincte du point de vue taxonomique et fonctionnel, en raison d'un nombre plus élevé d'insectivores de sous-étage et de frugivores de canopée. En comparaison, les omnivores associés aux milieux modifiés par les humains ont été plus abondants dans les petits îlots. Ainsi, même si les îlots de forêts de nuages de taille moyenne ont montré une richesse spécifique plus élevée et des densités élevées, les grands massifs forestiers ont abrité une composition de communauté aviaire distincte, en particulier des insectivores et des frugivores. De plus, pour que la réponse sous-jacente à la fragmentation soit correctement étudiée, il faut comparer plusieurs attributs de communauté, comme la richesse, la densité, la composition et la dominance spécifique. Ainsi, la conservation des forêts de nuages devrait viser la préservation des grands îlots forestiers restants afin de maintenir l'ensemble des communautés aviaires et d'éviter les extinctions locales.

Key Words: bird density; community composition; fragmentation; habitat loss; species richness

\section{INTRODUCTION}

Few studies have evaluated avian responses to habitat fragmentation in the tropics via comparison of avian communities in continuous habitat with those in a fragmented landscape (Fahrig 2003, Robinson and Sherry 2012). This is of relevance because tropical birds may respond differently to habitat fragmentation than birds of temperate regions (Stratford and Robinson 2005). One study of rainforest fragmentation in Amazonian Brazil demonstrated that avian species richness increases with fragment size, suggesting a species-area

Address of Correspondent: Katherine Renton, Estación de Biología Chamela, Instituto de Biología Universidad Nacional Autónoma de México, A.P. 21, San Patricio, Jalisco, C.P. 48980, México, krenton@ib.unam.mx 
relationship (Bierregard et al. 1992), as has been found in other human-disturbed habitats in the Neotropics (MacGregor-Fors et al. 2011). Species composition of avian communities may also vary in fragmented forests because of reduced abundance and dispersal capabilities of specialist species (Bierregard et al. 1992). In particular, large-bodied frugivores and terrestrial or understory insectivores have been found to decline with tropical forest disturbance or habitat conversion (Sodhi et al. 2008, Sekercioglu 2012, Newbold et al. 2013). Other general avian responses to tropical rainforest fragmentation include a decreased annual adult survival probability in smaller fragments (RuizGutiérrez et al. 2008), decreased reproduction rates, increased antagonistic interactions with nest predators and brood parasites, and ultimately local extinctions (Bierregard et al. 1992, Fahrig 2003). However, we still have little information on the response of tropical bird communities to fragmentation of other tropical forest habitats (Robinson and Sherry 2012).

Cloud forests maintain a large number of endemic and threatened resident bird species, and also provide wintering habitat for many Neartic-Neotropical migratory species, making this habitat of ecological importance for avian conservation (Peterson et al. 1993, Hernández-Baños et al. 1995, Navarro-Sigüenza et al. 2014). Furthermore, cloud forests are naturally fragmented and restricted to mountain slopes, with a high species turnover of the plant community across elevations (Luna-Vega et al. 1999; García-Franco et al. 2008). Avian communities within these forests have a high degree of habitat specialization and low dispersal capabilities, which could make them particularly susceptible to habitat fragmentation (Stratford and Robinson 2005, Boscolo et al. 2008, Moore et al. 2008). Studies of cloud forest bird communities in Hidalgo, Mexico, found that forestinterior species, such as understory insectivores and large-bodied frugivores, had lower abundances in smaller fragments (MartínezMorales 2005a, 2005b, 2007). Another study of small fragments of tropical premontane cloud forest in Costa Rica found variability in species richness and species turnover rates among years for fragments smaller than 10 ha, whereas larger fragments had more stable community dynamics (Borgella and Gavin 2005). Nevertheless, it is still unclear how avian community density, composition, and dominance may vary with increased cloud forest fragmentation, an understanding of which would help to assess the conservation value of small cloud forest fragments.

We aimed to compare avian community measures across fragment patch size by assessing shifts in species richness, bird community density, composition, and evenness in cloud forest patches of different sizes in Veracruz, Mexico. We expected an increase in bird density and species richness as patch size increases, caused by the association of forest-interior species with larger forest tracts. Furthermore, because modified habitats have uneven communities (Cotgreave and Harvey 1994, Wittebolle et al. 2009, Mikkelson et al. 2011, Pautasso et al. 2011), we also predicted that the more even communities would be found in larger forest patches.

\section{METHODS}

\section{Study area}

This study was carried out in the highlands of central Veracruz, Mexico, (19³8'55" N, 96 $\left.54^{\prime} 54^{\prime \prime} \mathrm{W}\right)$ at 1000-2000 m above sea level. The region has a temperate-humid climate with mean temperature of $18^{\circ} \mathrm{C}$ and year-round rainfall of $1500-2000 \mathrm{~mm}$ annually (Williams-Linera et al. 2013). Cloud forests in the area have an average canopy height of $30 \mathrm{~m}$ and have a heterogeneous tree species composition, although Liquidambar spp., Fagus spp., Quercus spp., and Oreopanax spp. are most abundant. Most cloud forests in central Veracruz are located in the surroundings of the metropolitan area of Xalapa, Veracruz, Mexico, and Coatepec, a small-sized highly urbanized town (Williams-Linera et al. 2002). Major environmental threats to these forests are associated with human activities, such as seasonal agriculture (mainly sugarcane), cattle grazing, urban growth, and to a minor extent, practices that allow partial and limited landscape functionality, such as shadegrown coffee plantations and selective logging (Moguel and Toledo 1999, Williams-Linera et al. 2002, 2013). These anthropogenic activities have reduced to less than $50 \%$ the original extent of cloud forests in central Veracruz, creating a landscape dominated by an agricultural matrix with small isolated patches of cloud forest and a few large forest remnants (Williams-Linera et al. 2002).

\section{Survey site selection}

We used a multispectral SPOT 5 scene from central Veracruz to discriminate areas of cloud forest. Following a geometric correction, we fused the multispectral and panchromatic bands of the SPOT image to obtain an image that preserved the spatial detail of the panchromatic band (spatial resolution $=2.5 \mathrm{~m}$ ) and the radiometric characteristics of the multispectral image (spatial resolution $=10 \mathrm{~m}$ ). We classified the fused image with a supervised classification method using the software Geomatica 2012 (PCI Geomatics Enterprises 2010), obtaining an 81\% classification reliability for cloud forest. We selected areas of cloud forest within 1000-2000 $\mathrm{m}$ above sea level to limit potential altitudinal variation in plant species and avian diversity (Williams-Linera et al. 2002, Martínez-Morales 2005a). Of these, we identified 2462 cloud forest fragments that were grouped into 5 size categories (I: 1-3.4 ha; II: $3.5-12.1$ ha; III: $12.2-42.4$ ha; IV: $42.5-127.4$ ha; V: 127.45-519.7 ha). This categorization allowed a balanced sampling of an equal area of cloud forest coverage in each size category.

\section{Bird surveys}

We surveyed resident bird communities during the breeding season of June-September 2012, with a separation of 1-6 days between survey periods because of weather conditions and availability of local guides. We used variable-radius point counts (Ralph et al. 1996, Bibby et al. 2000), separated by a minimum distance of $200 \mathrm{~m}$ to ensure data independence (Bibby et al 2000). To avoid spatio-temporal pseudo-replication (Hurlbert 1984, 2004) and to have a balanced sampling design, we established 14 independent point counts distributed among the cloud forest fragments within each size category. These were distributed among 13 fragments in size category I, 11 fragments in size category II, 8 fragments in size category III, 3 fragments in size category IV, and 2 large cloud forest remnants in size category V. Thus, we conducted a total of 70 independent point counts, with 14 point counts in each fragment size category, covering a total of 37 forest fragments.

All surveys were conducted by the same observer (RR-H), and each point-count location was sampled only once to avoid pseudo- 
replicated counts. Surveys were conducted only in favorable weather conditions to avoid behavioral or environmental conditions that could decrease detectability. A count duration of 5 minutes was used at each point to reduce the probability of double-counting individuals, thereby avoiding violation of one of the most important assumptions for the calculation of distancecorrected density estimates (Bibby et al. 2000, Buckland et al. 1993, 2004). Surveys commenced after sunrise and ended around 11:00 AM Central Standard Time (summer savings time). During each count all birds seen or heard were recorded, and the radial distance from the observer to each individual bird was measured with a Vortex Ranger 1000 laser rangefinder. Each bird species recorded in surveys was classified in one of seven foraging guilds, based on the primary food resource identified from behavioral observations during fieldwork and using bibliographical information when field data were insufficient (Howell and Webb 1995, Schulenberg 2010).

\section{Statistical analysis}

To determine whether our sampling was representative, we calculated the overall sample coverage using Species Prediction and Diversity Estimation software (SPADE, Chao and Shen 2010), which uses the estimated sample coverage for rare species to provide a value for overall data coverage. We also tested whether our data were spatially correlated by conducting paired comparisons among all surveyed fragments using the $\beta_{\text {sim }}$ turnover index and regressed the results in relation to the distance between fragments. We used the $\beta_{\text {sim }}$ turnover index because of its sensitivity to contrasting samples with different species richness values (Koleff et al. 2003). If spatial correlation exists, $\beta_{\text {sim }}$ values should be higher in closer fragments and lower in more distant ones. We also performed a regression analysis between bird species richness and sampling site altitude to determine whether there were altitudinal effects in our data set.

We determined the statistical expectation of species richness $\left(\mathrm{S}_{\text {est }}\right)$ for each size category of cloud forest fragments using individualbased data calculation with EstimateS 9 (Colwell 2013). We generated a comparable group of rarefied species richness values by extrapolating all samples by 2.5 times at most to avoid unstable results (Colwell et al. 2012, Colwell 2013). To assess statistical differences in expected species richness among cloud forest fragment categories, we set an accumulated abundance cutoff value based on the lowest total abundance recorded for any of the size categories.

We estimated bird densities using all recorded individuals of all species for each of the fragment size categories and computed multispecies bird densities using Distance 6.0 (Thomas et al. 2010). Alldredge et al. (2007) demonstrated that pooling individuals of multiple species enables calculation of distancesampling density estimations as a function of the detection probabilities of all individuals and species recorded in the surveys, thereby correcting potential errors of overestimation or underestimation of density that may result from the presence of common or rare species (Buckland et al. 1993, 2004). Therefore, we followed the procedure suggested by Alldredge et al. (2007) and grouped individuals of species based on an a priori consideration of species likely to have similar detection probabilities and natural history traits (Ruiz-Gutiérrez et al. 2010). This produced three groups of species based on high, moderate, or low forest dependency, which were used for the calculation of density estimates for each fragment size category (see Table 1).

To determine whether bird species richness and community density values were statistically different among cloud forest size categories, we calculated $84 \%$ confidence intervals (CIs) for results obtained by EstimateS 9 and Distance 6.0, following detailed procedures provided in MacGregor-Fors and Payton (2013). We then compared $84 \%$ CIs among groups, and where these did not overlap, species richness and bird density estimates were considered as significantly different with an alpha of 0.05 (Payton et al. 2003, MacGregor-Fors and Payton 2013). This comparison robustly mimics the 0.05 probability obtained from statistical tests for symmetric and asymmetric CIs. For comparison of the summed density estimate of the three subgroups in each cloud forest size category, we used the mean upper and lower subgroup CIs.

We evaluated shifts in the species composition of avian communities among fragment size categories using an abundance-based Bray-Curtis multivariate cluster analysis (single linkage). This analysis outputs a dendrogram based on the similarity of compared conditions. We also performed an abundance-based Bray-Curtis multivariate cluster analysis to evaluate foraging composition of avian communities among fragment size categories.

Finally, we determined the evenness of resident bird communities using rank/abundance Whittaker plots (Magurran 2004) because these depict the species abundance distribution of a community. For each category of cloud forest fragment size, we ordered bird species according to the total number of individuals recorded. These plots give information on the evenness among communities, with steep slopes characteristic of assemblages dominated by a high abundance of fewer species and moderate slopes representing even communities where species have similar abundances (Magurran 2004). We performed paired comparisons among the slopes of the rank/abundance regression lines using analysis of covariance (ANCOVA) on log transformed data, because ranked abundances did not follow a normal distribution.

\section{RESULTS}

We obtained 1043 bird records pertaining to 88 resident species of 33 families. Tyrannidae was the most species-rich avian family with 12 species, followed by Trochiliadae with 8 species and Emberizidae with 7 species (Table 1). The species recorded in our surveys belonged to 7 foraging groups: insectivore $(43.2 \%)$, frugivore $(22.7 \%)$, granivore $(10.2 \%)$, nectarivore $(10.2 \%)$, omnivore $(8 \%)$, carnivore $(3.4 \%)$, and piscivore $(2.2 \%)$. Overall, the most common species were the Common Bush-Tanager (Chlorospingus flavopectus), Brown Jay (Psilorhinus morio), Great-tailed Grackle (Quiscalus mexicanus), and Goldencrowned Warbler (Basileuterus culicivorus).

Our calculations of the overall sample coverage showed that we recorded almost all species present in the surveyed space and time $(C=0.982)$, ensuring that our ecological comparisons are robust. We found no spatial correlation of species richness among fragments because the $\beta_{\text {sim }}$ turnover index for paired fragment comparisons was not related to distance $\left(r^{2}=0.0005, F_{1,665}=\right.$ $0.034, P=0.56$ ), and there was no relation of species richness to altitude of sampling site $\left(r^{2}=0.01, F_{1,35}=1.37, P=0.25\right)$. 
Avian Conservation and Ecology 10(2): 2

http://www.ace-eco.org/vol10/iss2/art2/

Table 1. Resident landbird species recorded in each cloud forest fragment size category in central Veracruz, Mexico. Foraging guild: F indicates fruit; N, nectar; A, arthropods; V, vertebrates; O, omnivore; G, grain/seeds; P, fish. Forest dependency: H indicates high; M, moderate; L, low. $\dagger$ represent species protected under Mexican wildlife law.

\begin{tabular}{|c|c|c|c|c|c|c|c|}
\hline \multirow[t]{2}{*}{ Species } & \multirow[t]{2}{*}{ Trophic group } & \multirow[t]{2}{*}{ Forest Dependency } & \multicolumn{5}{|c|}{ Cloud forest fragment size category } \\
\hline & & & $\begin{array}{c}1- \\
3.4\end{array}$ & $\begin{array}{l}3.5- \\
12.1\end{array}$ & $\begin{array}{l}12.2- \\
42.4\end{array}$ & $\begin{array}{l}42.5- \\
127.4\end{array}$ & $\begin{array}{c}127.45- \\
519.7\end{array}$ \\
\hline \multicolumn{8}{|l|}{ Cracidae } \\
\hline Ortalis vetula & $\mathrm{F}$ & $\mathrm{L}$ & & & & • & \\
\hline \multicolumn{8}{|l|}{ Ardeidae } \\
\hline Butorides virescens & $\mathrm{P}$ & M & - & & & • & \\
\hline \multicolumn{8}{|l|}{ Accipitridae } \\
\hline Buteo magnirostris & $\mathrm{V}$ & $\mathrm{L}$ & - & - & - & & \\
\hline \multicolumn{8}{|l|}{ Columbidae } \\
\hline Patagioenas flavirostris & $\mathrm{F}$ & $\mathrm{L}$ & & & & - & \\
\hline Patagioenas fasciata & $\mathrm{F}$ & $\mathrm{H}$ & & & & & - \\
\hline Leptotila verreauxi & $\mathrm{F}$ & M & & - & • & - & \\
\hline \multicolumn{8}{|l|}{ Cuculidae } \\
\hline Piaya cayana & $\mathrm{O}$ & $\mathrm{L}$ & & & - & & \\
\hline \multicolumn{8}{|l|}{ Strigidae } \\
\hline Glaucidium brasilianum & $\mathrm{V}$ & $\mathrm{L}$ & & & $\cdot$ & • & \\
\hline \multicolumn{8}{|l|}{ Apodidae } \\
\hline Streptoprocne zonaris & A & $\mathrm{L}$ & & & - & & \\
\hline Chaetura vauxi & A & $\mathrm{L}$ & & • & & • & - \\
\hline \multicolumn{8}{|l|}{ Trochilidae } \\
\hline Phaethornis longirostris & $\mathrm{N}$ & M & & & & - & \\
\hline Campylopterus curvipennis & $\mathrm{N}$ & M & - & - & - & - & - \\
\hline Campylopterus hemileucurus & $\mathrm{N}$ & $\mathrm{H}$ & & & & & - \\
\hline Amazilia candida & $\mathrm{N}$ & $\mathrm{H}$ & & & • & - & \\
\hline Amazilia cyanocephala & $\mathrm{N}$ & $\mathrm{L}$ & - & - & • & - & \\
\hline Amazilia beryllina & $\mathrm{N}$ & M & & & & - & \\
\hline Amazilia yucatanensis & $\mathrm{N}$ & M & & - & - & & - \\
\hline Amazilia violiceps & $\mathrm{N}$ & M & & & & - & \\
\hline Hylocharis leucotis & $\mathrm{N}$ & $\mathrm{H}$ & • & & • & - & \\
\hline \multicolumn{8}{|l|}{ Trogonidae } \\
\hline Trogon caligatus & $\mathrm{F}$ & M & - & & - & - & - \\
\hline Trogon collaris $^{\dagger}$ & $\mathrm{F}$ & $\mathrm{H}$ & & & & • & • \\
\hline \multicolumn{8}{|l|}{ Momotidae } \\
\hline Momotus momota & $\mathrm{O}$ & $\mathrm{H}$ & $\cdot$ & - & • & - & \\
\hline \multicolumn{8}{|l|}{ Alcedinidae } \\
\hline Megaceryle torquata & $\mathrm{P}$ & $\mathrm{L}$ & & & & • & \\
\hline \multicolumn{8}{|l|}{ Picidae } \\
\hline Melanerpes formicivorus & A & $\mathrm{L}$ & - & - & - & - & $\cdot$ \\
\hline Melanerpes aurifrons & A & $\mathrm{L}$ & - & - & - & - & \\
\hline Picoides scalaris & A & M & - & - & • & • & \\
\hline Picoides fumigatus & A & $\mathrm{H}$ & & & & & - \\
\hline Colaptes rubiginosus & A & $\mathrm{H}$ & & & - & - & - \\
\hline Colaptes auratus & A & $\mathrm{H}$ & & $\cdot$ & & & \\
\hline \multicolumn{8}{|l|}{ Falconidae } \\
\hline Micrastur ruficollis ${ }^{\dagger}$ & $\mathrm{V}$ & $\mathrm{H}$ & & & & - & \\
\hline \multicolumn{8}{|l|}{ Psittacidae } \\
\hline Pionus senilis & A & M & & & & • & \\
\hline
\end{tabular}


Avian Conservation and Ecology 10(2): 2

Thamnophilidae

Thamnophilus doliatus

Furnariidae

Sittasomus griseicapillus

Tyrannidae

Camptostoma imberbe

Contopus pertinax

Contopus sordidulus

Empidonax occidentalis

Sayornis nigricans

Myiarchus tuberculifer

Pitangus sulphuratus

Megarynchus pitangua

Myiozetetes similis

Myiodynastes luteiventris

Tyrannus melancholicus

$\begin{array}{ll}\text { A } & \text { L } \\ \text { A } & \text { L } \\ \text { A } & \text { L } \\ \text { A } & \text { L } \\ \text { A } & \text { M } \\ \text { A } & \text { L } \\ \text { A } & \text { L } \\ \text { A } & \text { L } \\ \text { A } & \text { L } \\ \text { A } & \text { M } \\ \text { A } & \text { L }\end{array}$

Tityridae

Tityra semifasciata

Vireonidae

Vireo leucophrys

Corvidae

Psilorhinus morio

Hirundinidae

Hirundo rustica

Troglodytidae

Campylorhynchus zonatus

Troglodytes aedon

Pheugopedius maculipectus

Henicorhina leucosticta

L

L

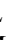

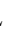

L

M

L

Cinclidae

Cinclus mexicanus ${ }^{\dagger}$

Turdidae

Myadestes occidentalis

Catharus aurantiirostris

Catharus occidentalis $^{\dagger}$

Catharus mexicanus

Turdus grayi

Turdus assimilis

Mimidae

Melanotis caerulescens

Ptiliogonatidae

Ptiliogonys cinereus

Parulidae
Setophaga pitiayumi

Basileuterus rufifrons

Basileuterus belli

Basileuterus culicivorus

A

A

A

Thraupidae

Thraupis abbas

M

G

Emberizidae

Sporophila torqueola

$\mathrm{L}$
M

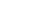

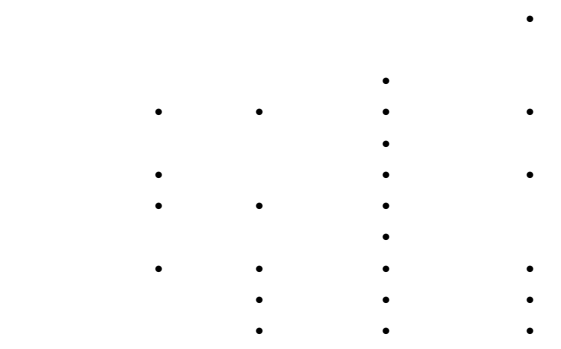

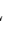

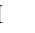

M

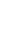

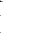


Arremon brunneinucha

Arremonops rufivirgatus

Atlapetes albinucha

Atlapetes pileatus

Aimophila rufescens

Chlorospingus flavopectus

Cardinalidae

Saltator atriceps

Piranga leucoptera

Cyanocompsa parellina

Icteridae

Dives dives

Quiscalus mexicanus

Molothrus aeneus

Icterus gularis

Psarocolius montezuma

Fringilidae

Euphonia affinis

Euphonia hirundinacea

Euphonia elegantissima

Haemorhous mexicanus

Spinus notatus

Spinus psaltria

G
G
G
G
G
F


F
F
G

$\begin{array}{llll}\mathrm{H} & \cdot & \cdot & \cdot \\ \mathrm{M} & & & \cdot \\ \mathrm{H} & & & \cdot \\ \mathrm{H} & \cdot & \cdot & \cdot \\ \mathrm{M} & & \cdot & \\ \mathrm{M} & & \cdot \\ \mathrm{L} & & \cdot \\ \mathrm{M} & & \cdot & \cdot\end{array}$

$\begin{array}{lr}\mathrm{O} & \mathrm{L} \\ \mathrm{O} & \mathrm{L} \\ \mathrm{O} & \mathrm{L} \\ \mathrm{F} & \mathrm{M} \\ \mathrm{F} & \mathrm{M}\end{array}$

We found significant variation in avian species richness among size categories of cloud forest fragments. The highest species richness $\left(\mathrm{S}_{\mathrm{est}}=70 ; 84 \% \mathrm{CI}\right.$ : 59.9-80.1) was recorded in mediumsized forest fragments (12.2-42.4 ha), which was statistically different from the species richness of larger forest fragments in categories IV $\left(\mathrm{S}_{\mathrm{est}}=48 ; 84 \% \mathrm{CI}\right.$ : $\left.39.9-56.1\right)$ and V $\left(\mathrm{S}_{\mathrm{est}}=46 ; 84 \%\right.$ CI: 35.6-56.4), as well as that in category II, which had the second smallest fragment size $\left(\mathrm{S}_{\text {est }}=40 ; 84 \% \mathrm{CI}\right.$ : 34.3-45.7; Fig. 1A). The category with the smallest cloud forest fragment size $(<3.4$ ha) had intermediate species richness $\left(\mathrm{S}_{\mathrm{est}}=52 ; 84 \% \mathrm{CI}\right.$ : 41.1-62.9), which did not differ significantly from that of the other fragment size categories (Fig. 1A).

Bird densities of the surveyed avian communities also varied significantly among size categories of cloud forest fragments (Fig. 1B). Overall, bird community density was lowest ( 9.4 birds per hectare, mean $84 \% \mathrm{CI}: 7.3-14.2)$ in the smallest category of forest fragments $(<3.4 \mathrm{ha})$ and differed significantly from avian density in medium-sized and large fragments (Fig. 1B). By comparison, the highest estimate of bird community density was determined for the intermediate-size category III (22.0 birds per hectare, mean 84\% CI: 18.6-42.2; Fig. 1B), although this did not differ significantly from community density in the other size classes of fragments larger than 3.5 ha (Fig. 1B). In general, species with high forest dependency had low densities, and most of the variation in bird density among size classes of cloud forest fragments was provided by species with low forest dependency, particularly in fragments in category III (Table 2).

Multivariate Bray-Curtis cluster analysis differentiated as a separate group the resident bird community in the largest forest fragments $(>127.5$ ha; Fig. 2A). This was because of the association of distinct avian species with large cloud forest fragments, specifically the Brown-backed Solitaire (Myiadestes occidentalis), Gray Silky-flycatcher (Ptiliogonis cinereus), Black-
Fig. 1. Variation in avian diversity among five cloud forest size categories in central Veracruz for (A) estimated avian species richness with $84 \%$ confidence intervals and (B) sum of estimated bird density from three forest dependency subgroups, with mean $84 \%$ confidence intervals, for each cloud forest fragment size category. Letters above values for each fragment size category indicate statistically significant differences among groups.
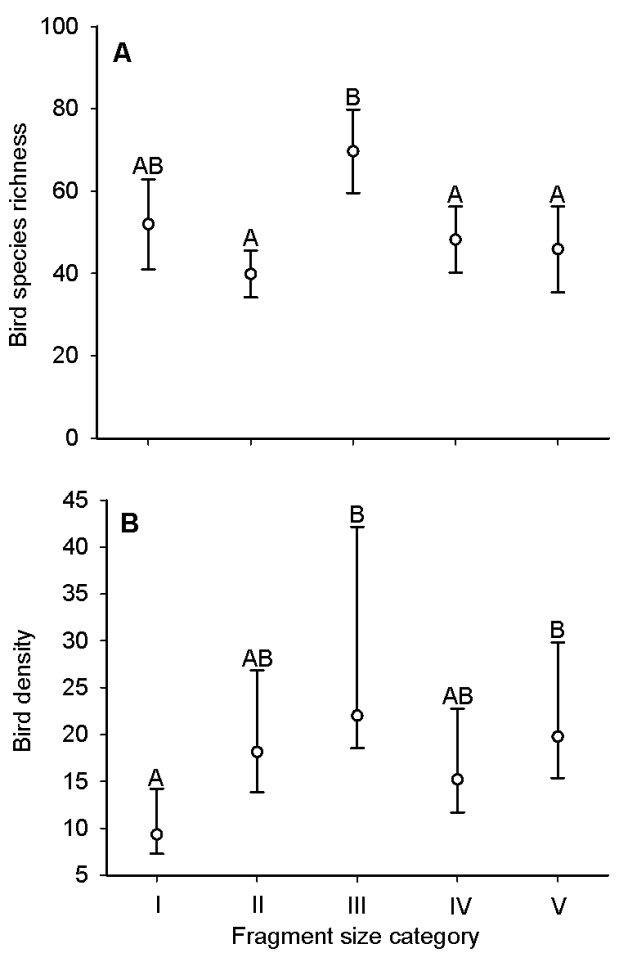
headed Nightingale-Thrush (Catharus mexicanus), and Rufouscapped Brush-Finch (Atlapetes pileatus), which all had higher abundances in the largest fragments. On the other hand, avian brood parasites such as the Bronzed Cowbird (Molothrus aeneus) were only found in smaller-sized fragments $(<12.2$ ha, categories I and II). Cloud forest fragments in the largest fragment size category were also differentiated from the other fragment size categories when we grouped avian communities by primary foraging guild (Fig. 2B). Larger forest fragments were dominated by insectivorous and frugivorous birds, which constituted $75 \%$ of the foraging guild records, whereas carnivorous species were not recorded. Moreover, the omnivore guild represented a significant part of the avian community in forest fragments smaller than 127.4 ha, whereas only one individual of this guild was recorded in the largest forest fragments. Finally, when considering either avian community composition or foraging guild, small and medium-sized fragment categories were clustered (categories I, II, and III), although the smaller fragments (categories I and II) had higher similarities than medium-sized fragments of categories III and IV (Fig. 2A, B).

Table 2. Estimated bird densities, with $84 \%$ confidence intervals (CIs), for avian species grouped by three categories of forest dependency in each of the five cloud forest fragment size categories. Category I: 1-3.4 ha; category II: 3.5-12.1 ha; category III: $12.2-42.4$ ha; category IV: $42.5-127.4$ ha; category V: 127.45-519.7.

\begin{tabular}{llcccc}
\hline \hline $\begin{array}{l}\text { Fragment } \\
\text { size } \\
\text { category }\end{array}$ & $\begin{array}{l}\text { Forest } \\
\text { dependency }\end{array}$ & $\begin{array}{c}\text { Density } \\
\text { (individ- } \\
\text { uals per } \\
\text { hectare) }\end{array}$ & $\begin{array}{c}\text { Effective } \\
\text { Detection } \\
\text { Radius } \\
(\mathrm{m})\end{array}$ & $\begin{array}{c}\text { Lower } \\
84 \% \mathrm{CI}\end{array}$ & $\begin{array}{c}\text { Upper } \\
84 \% \mathrm{CI}\end{array}$ \\
\hline I & High & 2.51 & 39 & 1.29 & 4.86 \\
I & Moderate & 4.25 & 30.3 & 2.89 & 6.26 \\
I & Low & 2.59 & 43.7 & 1.93 & 3.48 \\
II & High & 8.01 & 27.9 & 4.72 & 13.58 \\
II & Moderate & 6.83 & 29.3 & 5.76 & 8.11 \\
II & Low & 3.32 & 38.4 & 2.48 & 4.45 \\
III & High & 3.99 & 33.7 & 3.05 & 5.21 \\
III & Moderate & 4.82 & 29.8 & 3.78 & 6.14 \\
III & Low & 13.22 & 22 & 3.57 & 49.01 \\
IV & High & 4.02 & 34.6 & 2.99 & 5.4 \\
IV & Moderate & 3.97 & 31.9 & 3.27 & 4.82 \\
IV & Low & 7.22 & 28 & 4.23 & 12.35 \\
V & High & 3.01 & 34.9 & 2.34 & 3.86 \\
V & Moderate & 7.95 & 26.3 & 5.87 & 10.77 \\
V & Low & 8.82 & 32.3 & 5.01 & 15.51 \\
\hline
\end{tabular}

Avian community evenness, assessed through the slopes of rankabundance plots, also varied significantly among forest fragment size categories (ANCOVA: $F_{1,219}=12.6, P<0.001$ ). Pairwise comparisons showed that the slope of medium-sized forest fragments (category III) differed significantly from that of the smaller and largest forest fragment size categories (Table 3). Medium-sized forest fragments in category III had a less steep slope, indicating a more even avian community. Despite the fact that the slope of category $\mathrm{V}$, which had the largest fragment size, did not differ statistically from the slopes of the smaller fragment size categories, there were differences in the dominant avian species found in the largest forest fragments. In general, forest fragments in the size categories of I to IV had similar sets of dominant species, with the Common Bush-Tanager, Goldencrowned Warbler, Great-tailed Grackle, and Brown Jay being among the most dominant species. Of these, the Brown Jay and Great-tailed Grackle are omnivore species often associated with human disturbance, whereas the Common Bush-Tanager and Golden-crowned Warbler occur in forest patches, forest edges, and secondary growth. By comparison, although the Common Bush-Tanager (17.7\% of records) was also the most dominant avian species in the largest cloud forest fragments (category V), these had a distinct set of additional dominant species, the Brownbacked Solitaire (16.7\%) and Black-headed Nightingale-Thrush $(6.7 \%)$, both of which inhabit humid forest with a dense understory, the latter species being subject to special protection under Mexican wildlife law (Semarnat 2010).

Fig. 2. Bray-Curtis group average link cluster analysis for (A) overall avian community composition (taxonomic similarity) and (B) main dietary resource groups of the bird community (functional similarity) for five size categories of cloud forest fragments in central Veracruz.
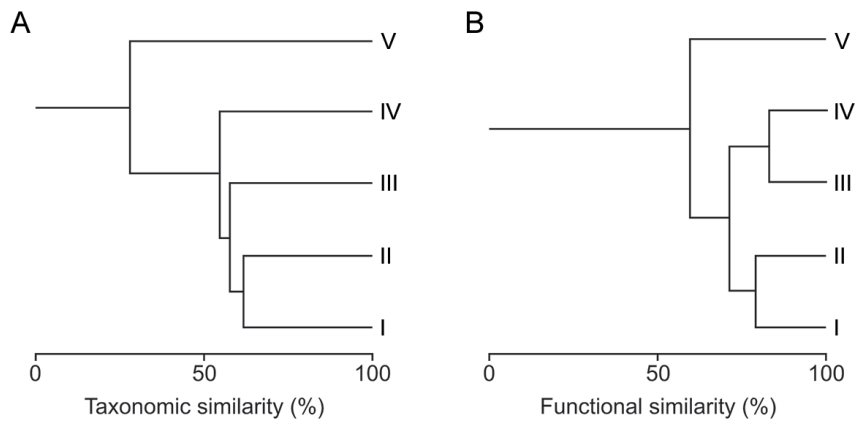

Table 3. Results of analysis of covariance paired comparisons of rank/abundance slopes among fragment size categories. Category I: 1-3.4 ha; category II: 3.5-12.1 ha; category III: 12.2-42.4 ha; category IV: 42.5-127.4 ha; category V: 127.45-519.7.

\begin{tabular}{lcc}
\hline \hline $\begin{array}{l}\text { Patch size } \\
\text { categories }\end{array}$ & $F$ & $P$ \\
\hline I vs II & 7.01 & 0.009 \\
I vs III & 16.3 & $<0.001^{*}$ \\
I vs IV & 5.06 & 0.027 \\
I vs V & 1.13 & 0.293 \\
II vs III & 35.6 & $<0.001^{*}$ \\
II vs IV & 21.7 & $<0.001^{*}$ \\
II vs V & 1.3 & 0.264 \\
IIIvs IV & 6.86 & $<0.05$ \\
III vs V & 14.1 & $<0.001^{*}$ \\
IV vs V & 6.67 & 0.011 \\
\hline
\end{tabular}

* = significant with Bonferroni correction to $\mathrm{P}<0.005$.

\section{DISCUSSION}

In our study, medium-sized cloud forest fragments of 12.2-42.4 ha (category III) had the highest avian species richness and more even communities, and reached an asymptote of bird density. This is consistent with similar results from studies addressing avian 
community diversity in disturbed and fragmented habitats (Collins et al. 1995, Graham and Duda 2011, Lee and Carroll 2014). According to the intermediate disturbance hypothesis (Connell 1978), this response may be caused by the exploitation of temporarily available resources by species from both natural and disturbed habitats, which are able to take advantage of medium-sized fragments. Hence, it may be that not all species recorded in medium-sized fragments are resident and breeding in these habitats, but may be using these fragments opportunistically (Tscharntke et al. 2008, Sekercioglu 2012). Blake and Hoppes (1986) found an increase in avian species soon after habitat disturbance, where birds were taking advantage of temporally available food resources. However, these communities may be unstable in terms of species turnover rates (Borgella and Gavin 2005), and we still require a deeper understanding of the underlying dynamics within and between patches and the mechanisms for the coexistence of species (Roxburgh et al. 2004). Moreover, medium-sized forest fragments (size category III: 12.2-42.4 ha) could be limited in nesting resources (Cornelius et al. 2008), suggesting that the persistence of populations in the long-term could be compromised if conservation efforts are simply directed at fragments with higher species richness.

Considering the similarities in bird community density of $\sim 19$ individuals per hectare in forest fragments larger than 3.5 ha, our results suggest that medium to large fragments reached the habitat carrying capacity, which may be greatly altered in smaller fragments because of the disruption of environmental conditions and ecological processes, such as resource availability/use dynamics (Hobbs and Hanley 1990). Despite the lack of statistical difference in the slope of the rank-abundance plots between the smallest and largest forest fragments, we found differences in bird density, supporting the idea of greater availability of resources in larger forest fragments (Hobbs and Hanley 1990). Although there may be high species turnover rates in cloud forests (Jankowski et al. 2013), we found an important variation in community composition for the largest fragment size category that was caused by changes in the abundance of forest understory and endemic species. Our results show that differences recorded in this study were mainly caused by the reduced numbers of forest-dependent understory insectivores in smaller forest fragments, possibly because of a greater influence of border effects (Banks-Leite et al. 2010) and the associated structural changes in vegetation in smaller fragments that benefit the presence of omnivore species (Jankowski et al. 2013).

Species composition of avian communities in large forest fragments was also ecologically distinct from that of any other forest fragment size category. In particular, understory insectivorous birds, such as the Rufous-capped Brush-Finch, Black-headed Nightingale-Thrush, and Brown-backed Solitaire, were associated with larger forest tracts. By comparison, dominant species in cloud forest fragments smaller than 12.2 ha (categories I and II) were the Great-tailed Grackle, Brown Jay, and Common Bush-Tanager; the first two are widespread species associated with disturbed habitats, and the latter is a common species in evergreen forest patches and edges (Howell and Webb 1995). This emphasizes the importance of more extensive areas of cloud forest, with potentially greater heterogeneity, for maintaining populations of threatened, endemic, and forestinterior species that may face higher risks of extirpation through the reduction of large forest remnants (Moore et al. 2008). Therefore, land-use change and habitat disturbance may be favoring the abundance of vagile generalists (Newbold et al. 2013), and ultimately, the presence of avian brood parasites because the Bronzed Cowbird was only recorded in forest fragments smaller than 12.2 ha. Hence, birds nesting in smaller cloud forest fragments would be more vulnerable to nest parasitism, contributing to the lower nest survival rates found in disturbed habitats (Alves Borges and Marini 2010). This accentuates the long-term importance of preserving larger cloud forest tracts as breeding habitat for resident species that provide important ecosystem services (Newbold et al. 2014).

Martínez-Morales $(2005 b, 2007)$ found a greater number of species in larger fragments, contrasting with our observed higher species richness in medium-sized fragments. This could be caused by the persistence of larger expanses of cloud forest, reaching 16,298 ha, in northeast Hidalgo (Martínez-Morales 2007), which provide avian communities with resistance to local extinctions (Brooks et al. 1999) and increase the likelihood of occurrence of forest-dependent species. Consequently, the presence of forestinterior species seems to be affected by characteristics generally associated with fragment size, such as fragment connectivity, increased border effect with fragment size reduction, time of fragment isolation, and the matrix in which the fragments are embedded (Hoover et al. 1995, Renjifo 1999, Ibarra-Macias et al. 2011). These factors may have a greater impact on forest-interior species, understory insectivores, and large-bodied frugivores because these species exhibit lower abundances in smaller fragments (Martínez-Morales 2005a,2005b, 2007); however, future studies are needed to validate the existence and extent of such patterns.

The naturally restricted and fragmented distribution of cloud forests, as well as the low dispersal capabilities of many cloud forest endemic birds (Bierregard et al. 1992), may limit the potential for individuals to use smaller forest fragments. This isolation of small forest patches through the process of anthropogenic fragmentation is one of the main sources of the loss of species that may occur in greater abundance in larger fragments (Turner 1996). Hence, cloud forest fragmentation may be a major threat for many endemic species (Peterson et al. 1993). As found in our study, fragments smaller than 12.2 ha may have low conservation value in terms of species richness, composition, and avian density, and may also have more unstable communities (Borgella and Gavin 2005). The shifts in avian community composition determined for large fragments in our study also emphasize the relevance of exploring community composition and not just focusing on species richness in relation to fragment size. Therefore, considering the complex turnover rates in species composition among fragments, future regional conservation efforts should address source-sink dynamics to maintain viable populations. In particular, it is important to maintain the integrity of large cloud forest fragments to improve the persistence of species with limited dispersal capacity, large area requirements, and forest-interior specialists, which could be lost from a landscape of small forest fragments.

Responses to this article can be read online at: http://www.ace-eco.org/issues/responses.php/751 


\section{Acknowledgments:}

The study was conducted in partial fulfillment of the requirements for a doctoral degree in Biological Sciences at the Universidad Nacional Autónoma de México (UNAM). Funding for the research was provided by the Programa de Apoyo a Proyectos de Investigación e Innovación Tecnológica (UNAM-DGAPA-PAPIIT grant IN203012) to KR. The Consejo Nacional de Ciencia $y$ Tecnología (CONACyT) provided a doctoral scholarship to $R R H$ (171086). Permits for the research were provided by the Secretaria del Medio Ambiente y Recursos Naturales (SEMARNAT) to KR. We thank Angelina Ruiz-Sanchez, Leonel-Herrera Alsina, and Angel Rueda-Hernández for field assistance and comments on earlier versions of the manuscript. We are grateful to Keith Hobson, the Subject Editor, and two anonymous reviewers for their constructive comments that enriched the quality of our paper.

\section{LITERATURE CITED}

Alldredge, M. W., K. H. Pollock, T. R. Simons, and S. A. Shriner. 2007. Multiple species analysis of point-count data: a more parsimonious modeling framework. Journal of Applied Ecology 44:281-290. http://dx.doi.org/10.1111/j.1365-2664.2006.01271.x

Alves Borges, F. J., and M. A. Marini. 2010. Birds nesting survival in disturbed and protected Neotropical savannas. Biodiversity and Conservation 19:223-236. http://dx.doi.org/10.1007/s10531-009-9718$\mathrm{z}$

Banks-Leite, C., R. E. Ewers, and J.-P. Metzger. 2010. Edge effects as the principal cause of area effects on birds in fragmented secondary forest. Oikos 119:918-926. http://dx.doi.org/10.1111/ j.1600-0706.2009.18061.x

Bibby, C. J., N. D. Burgess, D. A. Hill, and S. Mustoe. 2000. Bird census techniques. Academic Press, London, UK.

Bierregaard, R. O., Jr., T. T. Lovejoy, V. Kapos, A. A. dos Santos, and R. W. Hutchings. 1992. The biological dynamics of tropical rainforest fragments: a prospective comparison of fragments and continuous forest. BioScience 42:859-866. http://dx.doi. org/10.2307/1312085

Blake, J .G. H., and W. G. Hoppes. 1986. Influence of resource abundance on use of tree-fall gaps by birds in an isolated woodlot. Auk 103:328-340.

Borgella, R., Jr., and T. A. Gavin. 2005. Avian community dynamics in a fragmented tropical landscape. Ecological Applications 15:1062-1073. http://dx.doi.org/10.1890/04-0352

Boscolo, D., C. Candia-Gallardo, M. Awade, and J. P. Metzger. 2008. Importance of the interhabitat gaps and stepping-stones for lesser woodcreepers (Xiphorhynchus fuscus) in the Atlantic Forest, Brazil. Biotropica 40:273-276. http://dx.doi.org/10.1111/ j.1744-7429.2008.00409.x

Brooks, T. M., S. L. Pimm, and J. O. Oyugi. 1999. Time lag between deforestation and bird extinction in tropical forest fragments. Conservation Biology 13:1140-1150. http://dx.doi.org/10.1046/ j.1523-1739.1999.98341.x

Buckland, S. T., D. R. Anderson, K. P. Burnham, and J. L. Laake. 1993. Distance sampling: estimating abundance of biological populations. Chapman and Hall, London, UK.
Buckland, S. T., D. R. Anderson, K. P. Burnham, J. L. Laake, D. L. Borchers, and L. Thomas. 2004. Advanced distance sampling. Oxford University Press, Oxford, UK.

Chao, A., and T. J. Shen. 2010. Program SPADE (Species Prediction and Diversity Estimation). Program and user's guide. Institute of Statistics, National Tsing Hua University Hsin-Chu, Taiwan. [online] URL: http://chao.stat.nthu.edu.tw/software/ SPADE/SPADE_UserGuide.pdf

Collins, S. L., S. M. Glenn, and D. J. Gibson. 1995. Experimental analysis of intermediate disturbance and initial floristic composition: decoupling cause and effect. Ecology 76:486-492. http://dx.doi.org/10.2307/1941207

Colwell, R. K. 2013. EstimateS. Statistical estimation of species richness and shared species from samples. Version 9. [online] URL: http://purl.oclc.org/estimates

Colwell, R. K., A. Chao, N. J. Gotelli, S.-Y. Lin, C. X. Mao, R. L. Chazdon, and J. T. Longino. 2012. Models and estimators linking individual-based and sample-based rarefaction, extrapolation, and comparison of assemblages. Journal of Plant Ecology 5:3-21. http://dx.doi.org/10.1093/jpe/rtr044

Connell, J. H. 1978. Diversity in tropical rain forests and coral reefs. Science 199:1302-1310. http://dx.doi.org/10.1126/ science.199.4335.1302

Cornelius, C., K. Cockle, N. Politi, I. Berunsky, L. Sandoval, V. Ojeda, L. Rivera, M. Hunter, and K. Martin. 2008. Cavity-nesting birds in Neotropical forests: cavities as a potentially limiting resource. Ornitología Neotropical 19:253-268.

Cotgreave, P., and P. H. Harvey. 1994. Evenness of abundance in bird communities. Journal of Animal Ecology 63:365-374. http:// dx.doi.org/10.2307/5554

Fahrig, L. 2003. Effects of habitat fragmentation on biodiversity. Annual Review of Ecology, Evolution, and Systematics 34:487-515. http://dx.doi.org/10.1146/annurev.ecolsys.34.011802.132419

García-Franco, J. G., G. Castillo-Campos, K. Mehltreter, M. L. Martínez, and G. Vázquez. 2008. Composición florística de un bosque mesófilo del centro de Veracruz, México. Boletín de la Sociedad Botánica de México 83:37-52.

Graham, J. H., and J. J. Duda. 2011. The humpbacked species richness-curve: a contingent rule for community ecology. International Journal of Ecology 2011:868426. http://dx.doi. org/10.1155/2011/868426

Hernández-Baños, B. E., A. T. Peterson, A. G. Navarro-Sigüenza, and B. P. Escalante-Pliego. 1995. Bird faunas of the humid montane forests of Mesoamerica: biogeographic patterns and priorities for conservation. Bird Conservation International 5:251-277. http://dx.doi.org/10.1017/S0959270900001039

Hobbs, N. T., and T. A. Hanley. 1990. Habitat evaluation: do use/ availability data reflect carrying capacity? Journal of Wildlife Management 54:515-522. http://dx.doi.org/10.2307/3809344

Hoover, J. P., M. C. Brittingham, and L. J. Goodrich. 1995. Effects of forest patch size on nesting success of Wood Thrushes. Auk 112:146-155. http://dx.doi.org/10.2307/4088774 
Howell, S. N. G., and S. Webb. 1995. A guide to the birds of Mexico and northern central America. Oxford University Press, Oxford, UK.

Hurlbert, S. H. 1984. Pseudoreplication and the design of ecological field experiments. Ecological Monographs 54:187-211. http://dx.doi.org/10.2307/1942661

Hurlbert, S. H. 2004. On misinterpretations of pseudoreplication and related matters: a reply to Oksanen. Oikos 104:591-597. http:// dx.doi.org/10.1111/j.0030-1299.2004.12752.x

Ibarra-Macias, A., W. D. Robinson, and M. S. Gaines. 2011. Forest corridors facilitate movement of tropical forest birds after experimental translocations in a fragmented Neotropical landscape in Mexico. Journal of Tropical Ecology 27:547-556. http://dx.doi.org/10.1017/S0266467411000186

Jankowski, J. E., C. L. Merkord, W. Farfan Rios, K. García Cabrera, N. Salinas Revilla, and M. R. Silman. 2013. The relationship of tropical bird communities to tree species composition and vegetation structure along an Andean elevational gradient. Journal of Biogeography 40:950-962. http:// dx.doi.org/10.1111/jbi.12041

Koleff, P., K. J. Gaston, and J. J. Lennon. 2003. Measuring beta diversity for presence-absence data. Journal of Animal Ecology 72:367-382. http://dx.doi.org/10.1046/j.1365-2656.2003.00710.x

Lee, M.-B., and J. P. Carroll. 2014. Avian diversity in pine forests along an urban-rural/agriculture-wildland gradient. Urban Ecosystems http://dx.doi.org/10.1007/s11252-014-0421-9

Luna Vega, I., O. Alcántara-Ayala, D. Espinosa Organista, and J. J. Morrone. 1999. Historical relationships of the Mexican cloud forests: a preliminary vicariance model applying Parsimony Analysis of Endemicity to vascular plant taxa. Journal of Biogeography 26:1299-1305. http://dx.doi.org/10.1046/ j.1365-2699.1999.00361.x

MacGregor-Fors, I., L. Morales-Pérez, and J. E. Schondube. 2011. Does size really matter? Species-area relationships in human settlements. Diversity and Distributions 17:112-121. http://dx.doi. org/10.1111/j.1472-4642.2010.00714.X

MacGregor-Fors, I., and M. E. Payton. 2013. Contrasting diversity values: statistical inferences based on overlapping confidence intervals. PLoS ONE 8(2):e56794. http://dx.doi. org/10.1371/journal.pone.0056794

Magurran, A. E. 2004. Measuring biological diversity. Blackwell Publishing, Oxford, UK.

Martínez-Morales, M. A. 2005a. Landscape patterns influencing bird assemblages in a fragmented neotropical cloud forest. Biological Conservation 121:117-126. http://dx.doi.org/10.1016/j. biocon.2004.04.015

Martínez-Morales, M. A. 2005b. Nested species assemblages as a tool to detect sensitivity to forest fragmentation: the case of cloud forest birds. Oikos 108:634-642. http://dx.doi.org/10.1111/ j.0030-1299.2005.13706.x

Martínez-Morales, M. A. 2007. Avifauna del bosque mesófilo del noreste de Hidalgo, México. Revista Mexicana de Biodiversidad 78:149-162.
Mikkelson, G. M., B. J. McGill, S. Bealieu, and P. L. Beukema. 2011. Multiple links between species diversity and temporal stability in bird communities across North America. Evolutionary Ecology Research 13:361-372.

Moguel, P., and V. M. Toledo. 1999. Biodiversity conservation in traditional coffee systems of Mexico. Conservation Biology 13:11-21. http://dx.doi.org/10.1046/j.1523-1739.1999.97153.x

Moore, R. P., W. D. Robinson, I. J. Lovette, and T. R. Robinson. 2008. Experimental evidence for extreme dispersal limitation in tropical forest birds. Ecology Letters 11:960-968. http://dx.doi. org/10.1111/j.1461-0248.2008.01196.x

Navarro-Sigüenza, A. G., M. F. Rebón-Gallardo, A. GordilloMartínez, A. T. Peterson, H. Berlanga-García, and L. A. SánchezGonzález. 2014. Biodiversidad de aves en México. Revista Mexicana de Biodiversidad 85:476-495.

Newbold, T., J. P. W. Scharlemann, S. H. M. Butchart, C. H. Şekercioğlu, R. Alkemade, and D. W. Purves. 2013. Ecological traits affect the response of tropical forest bird species to landuse intensity. Proceedings of the Royal Society B: Biological Sciences 280:20122131. http://dx.doi.org/10.1098/rspb.2012.2131

Newbold, T., J. P. W. Scharlemann, S. H. M. Butchart, C. H. Şekercioğlu, L. Joppa, R. Alkemade, and D. W. Purves. 2014. Functional traits, land-use change and the structure of present and future bird communities in tropical forests. Global Ecology and Biogeography 23:1073-1084. http://dx.doi.org/10.1111/ geb. 12186

Pautasso, M., K. Böhning-Gaese, P. Clergeau, V. R. Cueto, M. Dinetti, E. Fernández-Juricic, M. L. Kaisanlahti-Jokimäki, J. Jokimäki, M. L. McKinney, N. S. Sodhi, D. Storch, L. Tomialojc, P. J. Weisberg, J. Woinarski, R. A. Fuller, and E. Cantarello. 2011. Global macroecology of bird assemblages in urbanized and seminatural ecosystems. Global Ecology and Biogeography 20:426-436. http://dx.doi.org/10.1111/j.1466-8238.2010.00616.x

Payton, M. E., M. H. Greenstone, and N. Schenker. 2003. Overlapping confidence intervals or standard error intervals: what do they mean in terms of statistical significance? Journal of Insect Science 3(34):1-6. http://dx.doi.org/10.1673/031.003.3401

PCI Geomatics Enterprises Inc. 2010. Geomatica-10. Richmond Hill, Ontario, Canada.

Peterson, A. T., O. A. Flores-Villela, L. S. Leon-Paniagua, J. E. Llorente-Bousquets, M. A. Luis-Martinez, A. G. NavarroSiguenza, M. G. Torres-Chavez, and I. Vargas-Fernandez. 1993. Conservation priorities in Mexico: moving up in the world. Biodiversity Letters 1:33-38. http://dx.doi.org/10.2307/2999648

Ralph, C. J., R. Geupel, P. Pyle, T. E. Martin, D. F. DeSante, and B. Milá. 1996. Manual de métodos de campo para el monitoreo de aves terrestres. Gen. Tech. Rep. PSW-GTR-159. U.S. Department of Agriculture, Albany, California, USA.

Renjifo, L. M. 1999. Composition changes in a subandean avifauna after long-term forest fragmentation. Conservation Biology 13:1124-1139. http://dx.doi.org/10.1046/j.1523-1739.1999.98311. $\mathrm{X}$

Robinson, W. D., and T. W. Sherry. 2012. Mechanisms of avian population decline and species loss in tropical forest fragments. 
Journal of Ornithology 153(1, Suppl):141-152. http://dx.doi. org/10.1007/s10336-011-0806-y

Roxburgh, S. H., K. Shea, and J. B. Wilson. 2004. The intermediate disturbance hypothesis: patch dynamics and mechanisms of species coexistence. Ecology 85:359-371. http:// dx.doi.org/10.1890/03-0266

Ruiz-Gutiérrez, V., T. A. Gavin, and A. A. Dhondt. 2008. Habitat fragmentation lowers survival of a tropical forest bird. Ecological Applications 18:838-846. http://dx.doi.org/10.1890/07-1090.1

Ruiz-Gutiérrez, V., E. F. Zipkin, and A. A. Dhondt. 2010. Occupancy dynamics in a tropical bird community: unexpectedly high forest use by birds classified as non-forest species. Journal of Applied Ecology 47:621-630. http://dx.doi.org/10.1111/

j.1365-2664.2010.01811.x

Schulenberg, T. S., editor. 2010. Neotropical birds. Cornell Lab of Ornithology, Ithaca, New York, USA. [online] URL: http:// neotropical.birds.cornell.edu

Sekercioglu, C. H. 2012. Bird functional diversity and ecosystem services in tropical forests, agroforests and agricultural areas. Journal of Ornithology 153(1, Suppl):153-161. http://dx.doi. org/10.1007/s10336-012-0869-4

Semarnat. 2010. Norma oficial Mexicana NOM-059SEMARNAT-2010. Diario oficial de la Federación (DOF). Jueves 30 de Diciembre de 2010. Secretaría de Medio Ambiente y Recursos Naturales, Mexico City, Mexico.

Sodhi, N. S., M. R. C. Posa, T. M. Lee, and I. G. Warkentin. 2008. Perspectives in ornithology: effects of disturbance or loss of tropical rainforest on birds. Auk 125: 511-519. http://dx.doi. org/10.1525/auk.2008.1708

Stratford, J. A., and W. D. Robinson. 2005. Gulliver travels to the fragmented tropics: geographic variation in mechanisms of avian extinction. Frontiers in Ecology and the Environment 3:91-98. http://dx.doi.org/10.2307/3868515

Thomas, L., S. T. Buckland, E. A. Rexstad, J. L. Laake, S. Strindberg, S. L. Hedley, J. R. B. Bishop, T. A. Marques, and K. P. Burnham. 2010. Distance software: design and analysis of distance sampling surveys for estimating population size. Journal of Applied Ecology 47:5-14. http://dx.doi.org/10.1111/

j.1365-2664.2009.01737.x

Tscharntke, T., C. H. Sekercioglu, T. V. Dietsch, N. S. Sodhi, P. Hoehn, and J. M. Tylianakis. 2008. Landscape constraints on functional diversity of birds and insects in tropical agroecosystems. Ecology 89:994-951. http://dx.doi.org/10.1890/07-0455.1

Turner, I. M. 1996. Species loss in fragments of tropical rain forest: a review of the evidence. Journal of Applied Ecology 33:200-209. http://dx.doi.org/10.2307/2404743

Williams-Linera, G., R. H. Manson, and V. E. Insunza. 2002. La fragmentación del bosque mesófilo de montaña y patrones de uso del suelo en la región oeste de Xalapa, Veracruz, México. Madera y Bosques 8:73-89.

Williams-Linera G., M. Toledo-Garibaldi, and C. GallardoHernández. 2013. How heterogeneous are the cloud forest communities in the mountains of central Veracruz, Mexico? Plant Ecology 214:685-701. http://dx.doi.org/10.1007/s11258-013-0199-5

Wittebolle, L., M. Marzorati, L. Clement, A. Balloi, D. Daffonchio, K. Heylen, P. De Vos, W. Verstraete, and N. Boon. 2009. Initial community evenness favours functionality under selective stress. Nature 458:623-626. http://dx.doi.org/10.1038/ nature 07840
Editor-in-Chief: Keith A.Hobson

Subject Editor: Scott Wilson
Sponsored by the Society of Canadian Ornithologists and Bird Studies Canada Parrainée par la Société des ornithologistes du Canada et Études d'oiseaux Canada

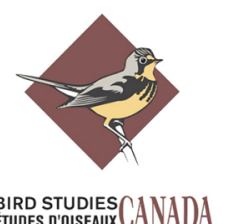

